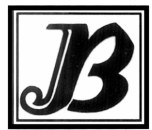

J. bio-sci. 22: 41- 44, 2014

ISSN 1023-8654

http://www.banglajol.info/index.php/JBS/index

\title{
MICROARCHITECTURAL STUDY OF THE OLFACTORY ORGAN OF DEVARIO REGINA (FOWLER, 1934) USING PAS TECHNIQUE
}

\section{Piyakorn Boonyoung ${ }^{1}$, Sinlapachai Senarat2, Jes Kettratad², Watiporn Yenchum ${ }^{3}$, Pisit Poolprasert 4 , Wannee Jiraungkoorskul5 *}

\author{
${ }^{1}$ Department of Anatomy, Faculty of Science, Prince of Songkla University, Songkhla 90110, Thailand \\ 2Department of Marine Science, Faculty of Science, Chulalongkorn University, Bangkok 10330, Thailand \\ ${ }^{3}$ Bio-Analysis Laboratory, Department of Chemical Metrology and Biometry, National Institute of Metrology \\ (Thailand), Pathum Thani 10120, Thailand \\ ${ }^{4}$ Program of Biology, Faculty of Science and Technology, Pibulsongkram Rajabhat University, Phitsanulok 65000, \\ Thailand \\ ${ }^{5}$ Department of Pathobiology, Faculty of Science, Mahidol University, Bangkok 10400, Thailand
}

\begin{abstract}
Context: Microarchitectural observation of the olfactory organ in Devario regina (Fowler, 1934) is still unknown.

Objectives: The normal histology and chemical detailed of glycoprotein in D. regina olfactory organ were investigated using histochemical analysis.

Materials and Methods: Fishes were collected from the Tapee River, Nakhon Si Thammarat Province, Thailand and were processed by the standard histological technique.

Results: Microarchitecture of olfactory organ revealed that it was a paired olfactory sac. Each sac was composed of the olfactory chamber and many lamellae surrounding by olfactory epithelium. This epithelium contained the differential cell types in both sensory (sensory ciliated cells) and non-sensory olfactory epithelium. The special localization of glycoprotein was intensively detected on the mucous cells.

Conclusion: This study provided the basic histology of the fish olfactory organ that will support the investigation regarding the physiological and ultrastructural analysis.
\end{abstract}

Key words: Fish, histology, histochemistry, periodic-acid Schiff

\section{Introduction}

In teleost, olfactory organ is essentially considered as chemoreception. It is well known that this organ directly interacts with the mediating behavior including feeding, predator detection and reproductive synchrony (Soresen and Caprio 1998). Therefore, it was exclusively attracted by several researchers concerning with the morphological and histological structures (Zielinski and Hara 1988). Nonetheless, only histology is exclusively examined of olfactory organ in many teleost due to providing the microscopic organization including Scyliorhinus canicula, Polypterus senegalus, Pangio kuhlii (Genten et al. 2008), Danio rerio (Menke et al. 2011), Oreochromis nilotica (Chakrabarti and Ghosh 2011a) and Terapon jarbua (Chakrabarti and Ghosh 2011b). Overall research showed that olfactory organ was a paired olfactory sac. Each sac was composed of olfactory chamber and many lamellae surrounded by olfactory epithelium. This epithelium contained two cell types viz., sensory and non-sensory olfactory epithelium. In this study, Devario regina was used considering it as an ornamental fish which is commonly found in natural habitat of Thailand. The objective was to examine the microarchitecture of olfactory organs using periodic acid-schiff (PAS) reaction.

*Corresponding author E-mail: wannee.jir@mahidol.ac.th 


\section{Materials and Methods}

Healthy adult fish $D$. regina $(n=20)$ were collected from the Tapee River, Chawang District, Nakhon Si Thammarat Province, Thailand $\left(8^{\circ} 28^{\prime} 10^{\prime \prime} \mathrm{N}, 9^{\circ} 29^{\prime} 45^{\prime \prime} \mathrm{E}\right)$ during the fishing season. These fishes were euthanized by rapidly cooling shock (Wilson et al. 2009) and were immediately fixed in Davidson's fixative for 36 hrs at room temperature. For histological analysis, these samples were processed by fixation, dehydration, embedding, sectioning and staining by the standard histological technique. Paraffin blocks were sectioned at 5-6 $\mu \mathrm{m}$ in thickness and stained with PAS (Bancroft and Gamble 2002).

\section{Results and Discussion}

The olfactory organ of $D$. regina was stained with PAS which could observe not only normal microarchitecture but also detection and localization of glycoprotein. In general, transverse sections of olfactory organ in $D$. regina was located in olfactory sacs on the snout of the head. It contained a paired of olfactory sac surrounded by fibrocatilage and hyaline cartilage. Each sac comprised the lamellar arrangement or olfactory folds (approximate $120 \mu \mathrm{m}$ in thickness) about 8-9 pieces which protruded into olfactory chambers (Fig. 1. A-B).

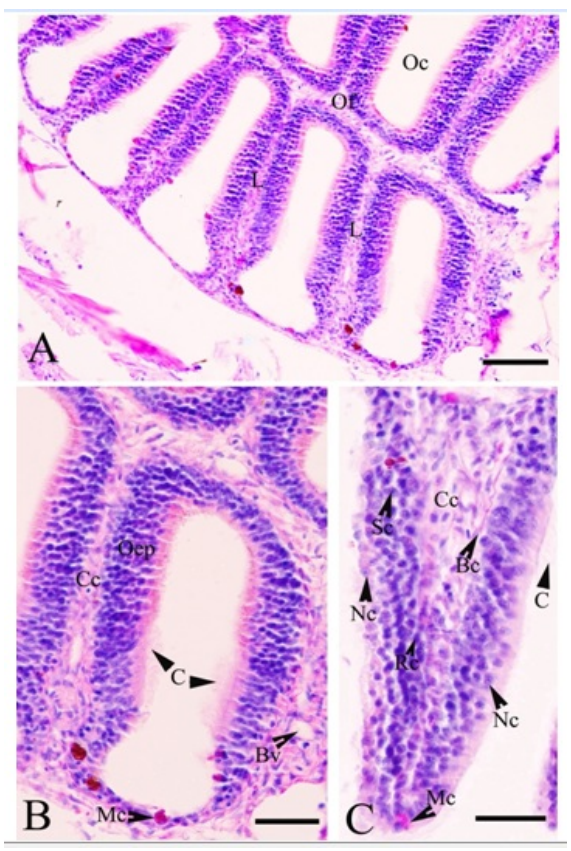

Fig.1. A - C. Micrograph of olfactory organ (Of) of Devario regina; $\mathrm{BC}=$ basal cell, $\mathrm{BV}=$ blood vessel, $\mathrm{C}=$ cilia, $C c=$ central core, $L=$ lamellae,$M c=$ mucous cells, $N c=$ nonsensory olfactory epithelium, $O c=$ olfactory chamber, Oep = olfactory epitheliums, Rc = sensory olfactory epithelium, Sc = supporting cell (A: 50 $\mu \mathrm{m}$; B-C: $20 \mu \mathrm{m}$.).

This discovery differs from Oreochromis nilotica, which is found to have about 19-20 pieces of arranging lamellar in each sac (Chakrabarti and Ghosh 2011a). Our observation revealed that each lamellar was lined by pseudostratified columnar epithelium. The thickness of the epithelial layer (about $20 \mu \mathrm{m}$ ) contained two distinct types; sensory and non-sensory olfactory epitheliums. The sensory epithelium or receptor cell was 
ciliated columnar stratified. Each cell was oval and prominent nucleus as basophilic part that was surrounded by eosinophilic cytoplasm. The non-sensory olfactory epithelium is characterized by oval nucleus as basophilic part and near with upper of epithelial surface. Other cells i.e., supporting, mucous and basal cells were also exhibited based on localization and histological characterization. This structure was similar to that of some other fishes such as P. kuhlii, P. senegalus (Genten et al. 2008) and D. rerio (Menke et al. 2011).

Among the various cell types of olfactory organ, both detection and localization of glycoprotein showed the ciliated sensory receptor cells of stratified epithelium. In addition, PAS reaction intensively showed reddish color in various mucous cells of the olfactory epithelium (Figures B-C), indicating the presence of glycoprotein. The present result was almost similar to those of reported in various teleost including Channa punctata (Datta and Singh, 1975), Cyprinus carpio (Ghosh and Chakrabarti 2012), Rita rita (Chakrabarti and Ghosh 2013). Olfactory epithelium and central core were separated by basement membrane. Central core contained the connective tissue and numerous capillaries.

It may be concluded that the olfactory organ in $D$. regina was composed of a paired olfactory sac. It consisted of many lamellae, which covered by olfactory epithelium. This epithelium contained two cell types, namely; sensory and non-sensory olfactory epithelium. However, these cells will be confirmed with immunocytochemistry again for further study. Observation from this study is considered to be the first report in Thailand which offers further detailed physiology and immunological examination.

\section{Acknowledgements}

The authors are thankful to Department of Anatomy, Faculty of Science, Prince of Songkla University, Songkhla, Thailand for their technical support in laboratory.

\section{References}

Bancroft J D, Gamble M. 2002. Theory and practice of histological Techniques. Churchill Livingstone. London.

Chakrabarti P, Ghosh S K. 2011a. Cytoarchitectural and surface ultrastructural analysis of the olfactory epithelium of Oreochrmis nilotica (Linnaeus). Folia Morphol 70, 143-148.

Chakrabarti P, Ghosh S K. 2011b. The structural organization and functional aspects of the olfactory epithelium of tigerperch, Terapon jarbua (Forsskål, 1775) (Perciformes: Terapontidae). Turk J Zool 35, 793-799.

Chakrabarti P, Ghosh S K. 2013. Histological and histochemical studies of the olfactory organ in bagrid catfish Rita rita (Hamiton, 1822). J Biol Sci 13, 242-249. http://dx.doi.org/10.3923/jbs.2013.242.249

Datta M J S, Singh S P. 1975. Histochemical observations on the olfactory mucosa of the indian green snake head fish, Channa punctata (Bloch) (Ophicephalidae). Proc Zool Soc 28, 1-13.

Ghosh S K, Chakrabarti P. 2012. Histochemical study of the olfactory resettle of Cyprinus carpio (Linnaeus, 1758). Iran J Fish Sci 11, 305-314.

Genten F, Terwinghe E, Danguy A. 2008. Atlas of Fish Histology. Enfield Science Publishers.USA.

Menke A L, Spitsbergen J M, Wolterbeek A P M, Woutersen R A. 2011. Normal anatomy and histology of the adult zebra fish. Toxic Patho 39, 759-775. http://dx.doi.org/10.1177/0192623311409597, PMid:21636695

Ojha P P, Kapoor A S. 1973. Structure and function of the olfactory apparatus in the freshwater carp, Labeo rohita (Ham. Buch). J Morphol 140, 77-85. http://dx.doi.org/10.1002/jmor.1051400107

Soresen P M, Caprio J. 1998.Chemoreception. In: Evens DH (Ed.). The Physiology of Fishes. CRC: Boca Raton, 251261. 
Wilson J M, Bunte R M, Carty A J. 2009.Evaluation of rapid cooling and tricaine methanesulfonate (MS222) as methods of euthanasia in zebrafish (Danio rerio). Am Assoc Lab Ani Sci 48, 785-789.

Zielinski B, HaraT J. 1988. Morphological and physiological development of olfactory receptor cells in rainbow trout (Salmo gairdneri) embryo.J Comp Neuro 271, 300-311. http://dx.doi.org/10.1002/cne.902710210 PMid:3379166 